\title{
Inclusive Education: a Descriptive Study In Sidoarjo Regency
}

\author{
Wiwik Dwi astutia ${ }^{\mathrm{a}}$ Anggun Dyah Anjarsari ${ }^{\mathrm{a}}$ \\ ${ }^{a}$ Program Studi Manajemen Pendidikan, Universitas PGRI Semarang \\ Semarang, Indonesia
}

Corresponding e-mail: nurkolis@upgris.ac.id

\begin{abstract}
Many children with special need can not go to school and get a proper education because of the school's distance is too far. Therefore, every sub-district should has at least one inclusion school for every level of education. Considering the analysis context, the researcher studies the inclusion education service, its supporting and inhibiting factors in Sidoarjo Regency from primary school, junior high school, until senior high. The methodology used in this research is qualitative descriptive. The researcher uses 23 sample school in Sidoarjo. The conclusions of this study indicated that the forms of educational services used in elementary, junior and senior high school are the regular form and the regular form with a pull out. Forms of support come from institutions, shadow teacher and the community, while the forms of barriers are derived from institutions and communities.
\end{abstract}

Keywords: inclusion education

\section{PRELIMINARY}

One of the basic rights of every individual is getting an education. Education is very important for human beings because it is expected to develop their potential owned so that they can fight in all competition of their life.

[1] "Educational services for special need students (ABK/Anak Berkebutuhan Khusus) at regular schools to develop cognitive, affective and psychomotor abilities. It is also confirmed by the official letter from the Directorate General of Basic Education (Dikdasmen) No.380 of 2003 which states "Inclusive education is an education service for $\mathrm{ABK}$ in regular schools so that $\mathrm{ABK}$ can learn and socialize with other reguler children.

Inclusive education is prepared to accommodate those who are unable to attend the special school (SLB/Sekolah Luar Biasa) because the distance to the school is not affordable. Ideally, in every regency or even district in Indonesia have an inclusive school. Sidoarjo is one of the cities in East Java which is appointed as the city of Inclusion. In every district in Sidoarjo must have an inclusive school at every level of education.

The school, which is appointed by the Education Office becomes an inclusive school, should bes ready to prepare. Inclusive education applied in Indonesia has different educational service models based on the potential and readiness of schools. The assumption that inclusion education is no different from mainstreaming in the opinion of Vaughn, Bos \& Schumn [2].

The implementation of inclusive education varies in many schools. It is based on the needs of the child, and the type of ABK's disability and the readiness of the school in its education services. The model of Inclusive Education is as follows: ABK learns and socializes together with regular students (full inclusion), ABK learns together with regular students by forming special groups (regular class model with cluster), ABK in a certain time studies in special classes but for subjects can be followed, the ABK learns together with regular students (regular classes with pull outs), the ABK learns together in the regular class by forming special groups, but if the ABK is not awkward to follow the lesson materials they will be placed in the source space (regular classes with clusters and pul out), ABK placement to study in regular classes with adaptation (special classes with integration), and $\mathrm{ABK}$ are placed in special classes at regular schools (special classes).

Sidoarjo regency has an inclusive school scattered in every district. Inclusive Education is conducted from elementary, junior high school until senior high schools. In the implementation of inclusive education is still found barriers so that the potential of ABK less developed

The purpose of this study is to describe objectively the inclusive education service in Sidoarjo regency. The benefits of this research are 
motivating Sidoarjo and other regencys in East Java in Inclusive education services, information and reference materials that can be used for science development, and increasing community support in inclusive education services.

\section{METHOD}

The research data is in the form of numbers, then analyzed by statistic and method used is quantitative method (Sugiyono, 2010: 13). Research conducted in this Sidoarjo regency including descriptive research, the resulting data is quantitative data, while data analysis is with percentage.

The variables in this study are the implementation of the Inclusive Education Service Model, so that the sub-variables that become the focus of the Research are the Inclusive Education Service Model, the Inclusive Education Support Factors and the Inclusive Education Inhibiting Factors

The population of this research are all elementary school (SD), junior high school (SMP), and senior high school (SMA) that conducting inclusive education. The total population in this study are 105 schools spread over 18 districts. SD
Inclusion in Sidoarjo Regency are 74 schools, SMP Inclusion in Sidoarjo Regency are 24, and SMA in sidoarjo regency are 7 schools. Selection of sample using Cluster Sampling technique (Area Sampling).

The sampling technique used in this study is chosen two stages, namely 1) determining the specific area (district) as the location of the research, 2) determining the research subject or inclusion school as the school where the data is collected.

Data collection is done by questionnaire and documentation. Questionnaire is a technique or way of collecting data indirectly. "The method of analysis of this document is the primary method if researchers conduct a content analysis approach. For research with other approaches, this method has an important position. The data obtained from document analysis can be used as supporting or complementary data "(Sudaryono, 2012: 41).

Analysis of the data to be produced by using some as suggested by Hadeli (2004: 24) is editing, encoding, and tabulation. The analysis method used in this study is Percentage Descriptive Analysis.

\section{RESULT}

1. Forms of Inclusive Education Services

Table 1. 1 Forms of Inclusive Education Services

\begin{tabular}{|ll|l|l|l|l|l|l|}
\hline \multirow{2}{*}{ Model of Inclusion Education Service } & \multicolumn{3}{|c|}{$\begin{array}{c}\text { Answer Sum } \\
\text { Skor Rill }\end{array}$} & \multicolumn{3}{c|}{ Calculation Result } \\
\cline { 3 - 8 } & SD & SMP & SMA & SD & SMP & SMA \\
\hline 1. & Reguler Class & $46 \%$ & $60 \%$ & $100 \%$ & $16 \%$ & $22 \%$ & $35 \%$ \\
\hline 2. & Reguler Class with Cluster & $40 \%$ & $80 \%$ & $66 \%$ & $14 \%$ & $28 \%$ & $22 \%$ \\
\hline 3. & Reguler Class with Pull Out & $80 \%$ & $60 \%$ & $33 \%$ & $28 \%$ & $22 \%$ & $11 \%$ \\
\hline 4. & Reguler Class with Cluster and Pull Out & $66 \%$ & $40 \%$ & $33 \%$ & $23 \%$ & $14 \%$ & $11 \%$ \\
\hline 5. & Reguler Class with varies Intregation & $40 \%$ & $20 \%$ & $33 \%$ & $14 \%$ & 75 & $11 \%$ \\
\hline 6. & Special Class & $13 \%$ & $20 \%$ & $33 \%$ & $5 \%$ & $7 \%$ & $11 \%$ \\
\hline & & 285 & 280 & 298 & $100 \%$ & $100 \%$ & $100 \%$ \\
\hline
\end{tabular}

Figure 4.1 Percentage of Inclusive Education Service Model at SD level in Sidoarj

\section{Support for Inclusive Education services}

Table 1.2 Support for Inclusive Education services

\begin{tabular}{|c|c|c|c|c|c|c|}
\hline \multirow{2}{*}{ Support of Inclusion Educator Service } & \multicolumn{3}{|c|}{$\begin{array}{c}\text { Number of Answers } \\
\text { (Rill Score) }\end{array}$} & \multicolumn{3}{|c|}{$\begin{array}{c}\text { Result of } \\
\text { Calculation }\end{array}$} \\
\cline { 2 - 7 } & SD & SMP & SM & S & S & S \\
\hline
\end{tabular}




\begin{tabular}{|c|c|c|c|c|c|c|}
\hline & & & $\mathrm{A}$ & $\mathrm{D}$ & MP & MA \\
\hline $\begin{array}{l}\text { 1. Attitude, Commitment and } \\
\text { Confidence }\end{array}$ & $80 \%$ & $80 \%$ & $100 \%$ & $23 \%$ & $29 \%$ & $29 \%$ \\
\hline 2. Facilities and Infrastructure & $66 \%$ & $60 \%$ & $80 \%$ & $19 \%$ & $21 \%$ & $22 \%$ \\
\hline 3. Educators & $73 \%$ & $80 \%$ & $80 \%$ & $21 \%$ & $29 \%$ & $22 \%$ \\
\hline 4. Learning System & $46 \%$ & $20 \%$ & $33 \%$ & $13 \%$ & $7 \%$ & $10 \%$ \\
\hline 5. Community Support & $86 \%$ & $40 \%$ & $66 \%$ & $24 \%$ & $14 \%$ & $18 \%$ \\
\hline Maximal Score & 351 & 280 & 359 & $100 \%$ & $100 \%$ & \\
\hline
\end{tabular}

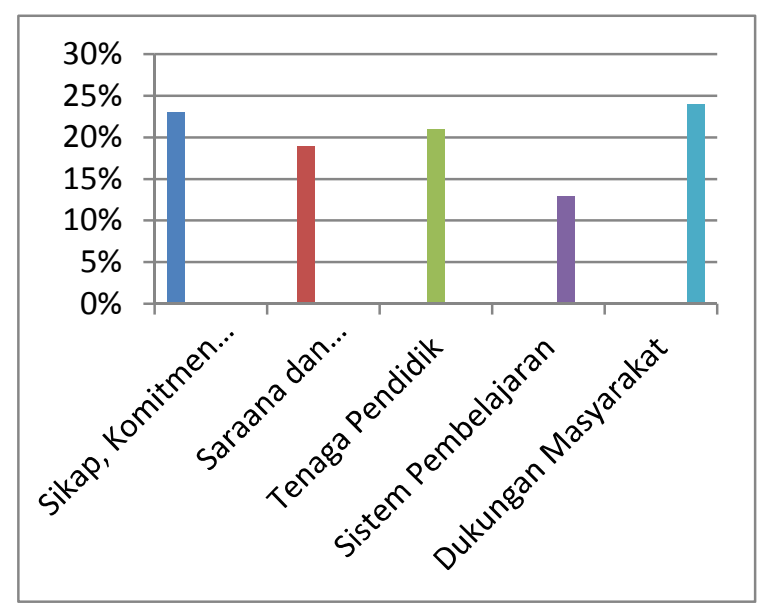

Figure 4.1 Percentage of Inclusive Education Service Model at SD level in Sidoarjo

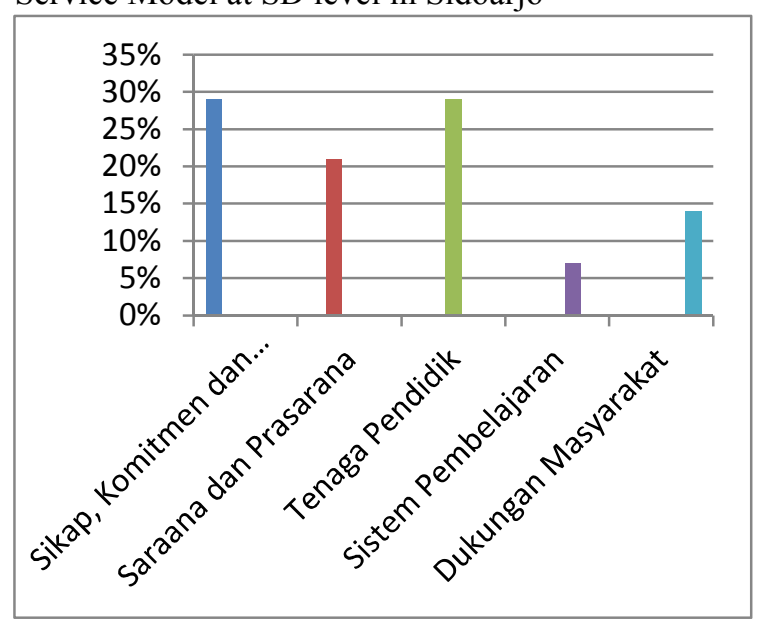

Figure 4.2 Support of Inclusive Education services In Sidoarjo at SD

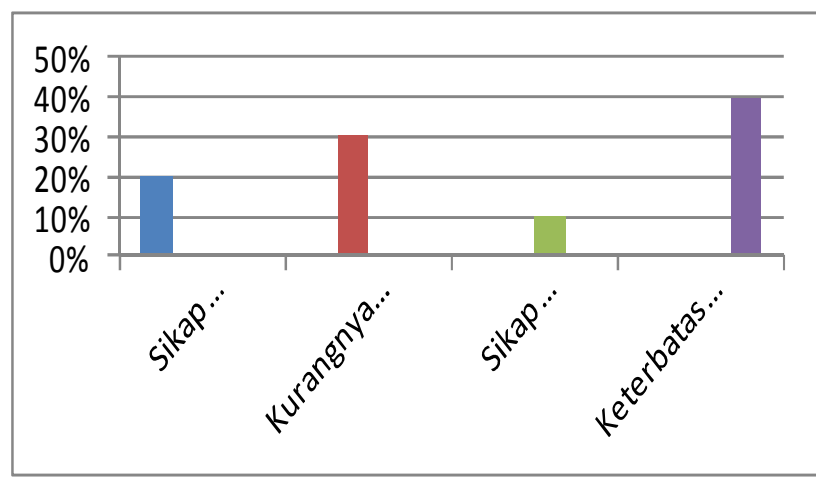

Figure 4.3 Support of Inclusive Education Services In Sidoarjo at Junior High Level

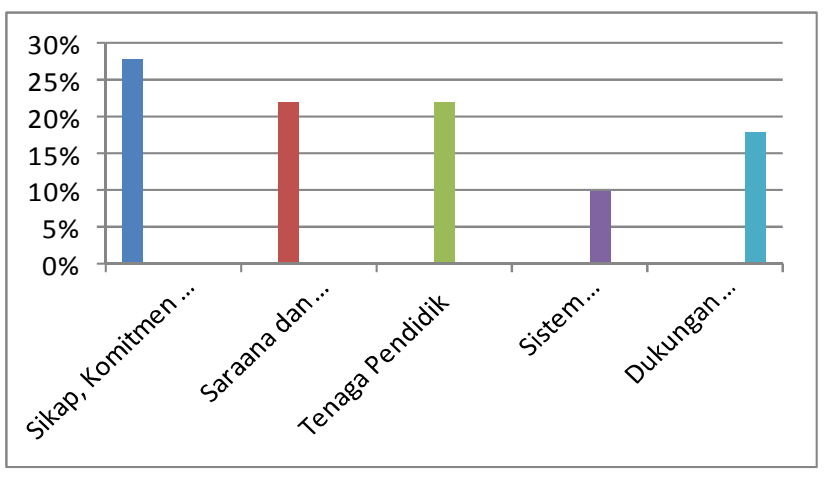

Figure 4.4 Support of Inclusive Education Services in Sidoarjo at High School Level

\section{Barriers to Inclusive Education services}

\begin{tabular}{|l|l|l|l|l|}
\hline \multicolumn{2}{|l|}{$\begin{array}{l}\text { Imber of Answers } \\
\text { (Rill Score) }\end{array}$} & \multicolumn{2}{|c|}{ Result of Calculation } \\
\hline SMP & SMA & SD & SMP & SMA \\
\hline
\end{tabular}




\begin{tabular}{|c|l|l|l|l|l|l|l|}
\hline 1. & $\begin{array}{l}\text { Negative Attitudes of School } \\
\text { Residents }\end{array}$ & $46 \%$ & $40 \%$ & $33 \%$ & $22 \%$ & $20 \%$ & $14 \%$ \\
\hline $\begin{array}{l}\text { 2. } \\
\text { Lack of Cooperation between } \\
\text { Inclusive and SLB Schools }\end{array}$ & $53 \%$ & $60 \%$ & $66 \%$ & $25 \%$ & $30 \%$ & $29 \%$ \\
\hline 3. & Attitude Learners & $40 \%$ & $20 \%$ & $33 \%$ & $19 \%$ & $10 \%$ & $14 \%$ \\
\hline 4. & $\begin{array}{l}\text { Limitations of Funds and } \\
\text { Educators }\end{array}$ & $73 \%$ & $80 \%$ & $100 \%$ & $34 \%$ & $40 \%$ & $43 \%$ \\
\hline Maximal Score & 212 & 200 & 232 & $100 \%$ & $100 \%$ & $100 \%$ \\
\hline
\end{tabular}

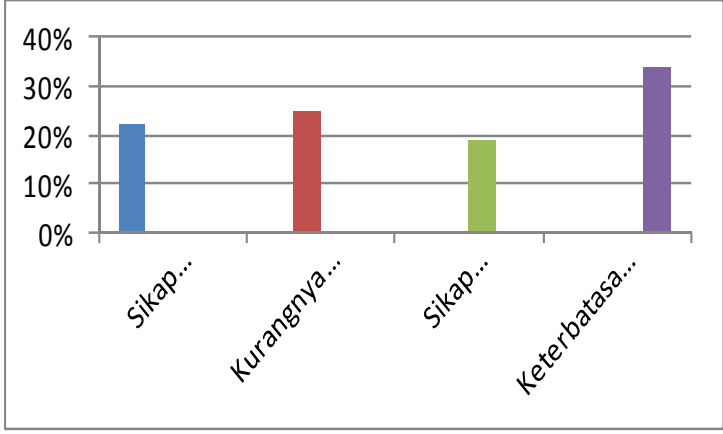

Figure 4.6 Barriers to Inclusive Education Services In Sidoarjo At High School Level

\section{DISCUSSION}

Inclusive Education: Descriptive studies in Sidoarjo District include the form of Inclusive Education services, support and barriers to inclusive education services. At elementary, junior and senior high school level with sample of 23 Inclusion schools in Sidoarjo Regency is $80 \%$, at elementary level is $\mathrm{u}$

sing Model of Regular Class with Pull Out. Regular class with Pull Out is mostly used in elementary level. Many elementary schools use this form because learners with special needs often follow difficulty in learning, located in the source room.

Students with special needs at elementary level still need a shadow teacher (GPK/Guru Pendamping Kelas) and calm atmosphere to be able to concentrate, learners with special needs often use room source. The use of resource space for the deepening of mathematics, English, and IPS subjects is carried out during school hours or after school. For ABK with the type of intellectual disabilitya and autism, the service in the resource room is done individually.

The $80 \%$ of Inclusive education at junior high school in Sidoarjo is applying the Regular Class Model with Cluster. This model is widely applied in junior high school (1) the number of GPK is limited (2) students with low visio and dislexia in one class, but for severe disorders such as autism is separated (3) social interaction learners with special needs is good at level SMP. Regular Class Model with this Cluster when applied in full will greatly affect the ability of social interaction for children with special needs. And cultivate mutual respect between students with special needs with normal students

The $100 \%$ of inclusive education at senior high school is using Regular Class form. This amount is surely a perfect number. All schools at senior high school apply the form of Regular Class. Learners at high school level are very able to Socialize with peers and able to follow the learning activities well. Participants with special needs who want to go to High School Inclusion School must have recommendation from junior high school or come from SMP inclusion also.

The support for implementation of inclusive education at elementary level in Sidoarjo Regency is $86.65 \%$ in the form of Community Support. The community is involved in various activities that is to bring the students with special needs and regular learners.

$80 \%$ school community such as principals, teachers, staff and parents have high confidence and commitment to support the success of Inclusive Education at junior high school level in Siodarjo District. The teacher's commitment in educating for each student as a duty and noble task to educate the child of the nation has been very maximum in Sidoarjo. While $100 \%$ at SMA level is the attitude, commitment and confidence of all citizens of the school.

While some barriers to Inclusive Education services in Sidoarjo both at elementary level, junior high and high school are the Limitations Fund and Educators who are experts in the field. Percentage of each level is $100 \%$ in elementary and high school level, $80 \%$ at junior high school level. This result show that funds and teachers who are experts in the field are very lacking. Based on research data, the salary received by GPK is very minimal even far 
below minimum level of salary (UMR/Upah Minimum Regional). In addition, another barrier is the lack of funds to buy equipment and learning media. GPK is expected to come from graduates of $\mathrm{S} 1$ special education in order to maximize learners leverage.

\section{CONCLUSIONS RECOMMENDATIONS}

AND

The forms of inclusive education services at elementary, junior and senior secondary levels are a regular form and a regular form with a pullout. Support for education services comes from institutions, teachers, and communities. While barriers to inclusive education services are related to GPK salaries, GPK capabilities in learning settings, lack of learning media

Suggestions for conductors of the Inclusive Education: for the principal the as organizer of inclusion is more communicating with the parties related to the special services, for example SLB, Psychiatrist, etc. GPK and class teacher in making lesson plan (RPP/Rencana Program Pembelajaran), Individualized Education Plan (PPI/Program
Pembelajaran Individu), and compensatory services. Parents who have Special Needs Children provide support both morally and materially, and the presence of special needs children may be accepted by the community as part of the community members and provide equal opportunities with other normal citizens.

\section{REFERENCE}

[1] Sunaryo. 2009. Manajemen Pendidikan Inklusi: Konsep, Kebijakan, dan implemantasinya DalamPendidikanLuaRBiasa.Online)

[2] Efendi, Muhammad. 2013. Persepektif Pendidikan Inklusi. Malang : Pendidikan Luar Biasa Univeritas Negeri Malang

[3] Hadeli. 2006. Metode Penelitian Pendidikan. Jakarta : Quantum Teaching

[4] Sugiyono. 2013. Metode Penelitian Kualitatif, Kuantitatif dan R\&D. Bandung: Alfabeta

[5] Sugiyono. 2013. Metode Penelitian Pendidikan. Bandung: Alfabeta.

[6] (hhtp//filu.upi.edu/Direktori/FIP/JUR_PEND_LUAR _BIASA_MakalahSunaryoMakalah_Inklusif.Pdf) Diakses tanggal 4 Januari 2015. 